\title{
Crime, Hysteria and Belle Époque Hypnotism: The Path Traced by Jean-Martin Charcot and Georges Gilles de la Tourette
}

\author{
Julien Bogousslavsky ${ }^{a}$ Olivier Walusinski ${ }^{b}$ Denis Veyrunes ${ }^{c}$ \\ ${ }^{a}$ Department of Neurology and Neurorehabilitation, Clinique Valmont, Genolier Swiss Medical Network, \\ Glion/Montreux, Switzerland; ${ }^{\mathrm{b}}$ The Walusinski Library, Brou, and ${ }^{\mathrm{c} S}$ Schizolex, Nicolas Noilhan, Paris, France
}

\section{Key Words}

Hypnotism - Hysteria - Crime - Charcot, Jean-Martin · Gilles de la Tourette, Georges $\cdot$ La Salpêtrière $\cdot$ Nancy School

\begin{abstract}
Hysteria and hypnotism became a favorite topic of studies in the fin de siècle neurology that emerged from the school organized at La Salpêtrière by Jean-Martin Charcot, where he had arrived in 1861. Georges Gilles de la Tourette started working with Charcot in 1884 and probably remained his most faithful student, even after his mentor's death in 1893. This collaboration was particularly intense on 'criminal hypnotism', an issue on which Hippolyte Bernheim and his colleagues from the Nancy School challenged the positions taken by the Salpêtrière School. Bernheim claimed that hypnotism was not a diagnostic feature of hysteria and that there were real-life examples of murders suggested under hypnosis, while hypnosis susceptibility was identified with hysteria by Charcot and Gilles de la Tourette, who saw rape as the only crime associated with hypnotism. The quarrel was particularly virulent during a series of famous criminal cases which took place between 1888 and 1890. At the time, it was considered that La Salpêtrière had succeeded over Nancy, since the role of hypnotism was discarded during these famous trials. However, the theories of Charcot and Gilles de la Tourette were also damaged by the fight, which probably triggered the conceptual evolution leading to Jo-
\end{abstract}

seph Babinski's revision of hysteria in 1901. Gilles de la Tourette's strong and public interest in hypnotism nearly cost him his life, when a young woman who claimed to have been hypnotized against her will shot him in the head at his own home in 1893. It was subsequently shown that hypnotism had nothing to do with it. The delusional woman was interned at Sainte-Anne for mental disturbance, thus escaping trial. Ironically, Gilles de la Tourette may have been partly responsible, since he had been one of the strongest proponents of placing mentally-ill criminals in asylums instead of prisons.

Copyright $\odot 2009$ S. Karger AG, Basel

\section{Introduction}

La Salpêtrière is a hospital where, in the middle of the nineteenth century, diseases of the nervous system started to get organized into what would become modern neurology. After he was appointed at La Salpêtrière on November 13, 1861, Jean-Martin Charcot became the driving force of this evolution. Soon, he was surrounded by students and colleagues, forming what would become known as the Salpêtrière School. These included Victor Cornil, Charles Bouchard, Charles Féré, Paul Richer, Fulgence Raymond, Pierre Marie, Henri Meige and many others, among whom Joseph Babinski and Paul Sollier were said to be his most gifted followers [1]. Georges

\section{KARGER}

Fax +41613061234 E-Mail karger@karger.ch www.karger.com
(C) 2009 S. Karger AG, Basel

0014-3022/09/0624-0193\$26.00/0

Accessible online at:

www.karger.com/ene
Julien Bogousslavsky

Department of Neurology and Neurorehabilitation, Clinique Valmont

Genolier Swiss Medical Network

CH-1823 Glion/Montreux (Switzerland)

Tel. +41 21962 3701, Fax +41 21962 3838, E-Mail jbogousslavsky@valmontgenolier.ch 


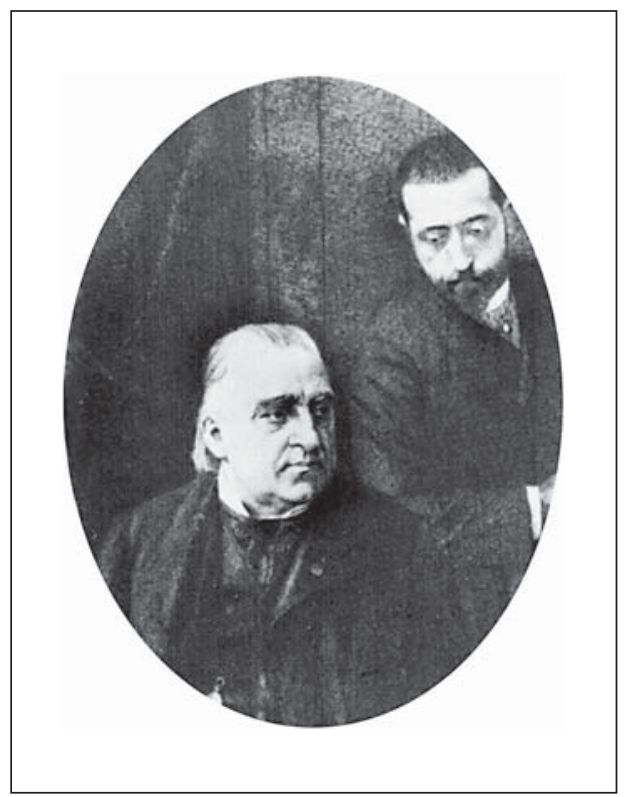

Fig. 1. Jean-Martin Charcot and Georges Gilles de la Tourette.

Gilles de la Tourette belonged to the group of students closest to Charcot. He started work with Charcot in 1884 as an intern, advancing to chef de clinique in 1887 and became Charcot's personal secretary in 1892 (fig. 1). While Gilles de la Tourette is now specifically associated with the disease that bears his name, at the time his most recognized activity was clearly in the management of hysterics and hypnotism [2].

\section{Hysteria and Hypnotism in Charcot's Circle}

In neurology, the second half of the nineteenth century was dominated by the study of two diseases, tabes and hysteria. Probably resulting from the suggestion of his intern Désiré-Magloire Bourneville [3], Charcot's interest in hysteria developed mainly after 1870 when he took charge of the Delasiauve service, a place where mainly epileptics and hysterics were admitted [4]. This interest also developed at a time when the general public was fascinated in 'animal magnetism' and 'mesmerization' (fig. 2). This fascination often led to occult practices and charlatanism, which had gained a considerable foothold after the studies of Franz Anton Mesmer at the end of the eighteenth century. The medical field also had its share of distortion, as shown by the experiments of Jules Bernard Luys [5], when they became used by his chef de cli-

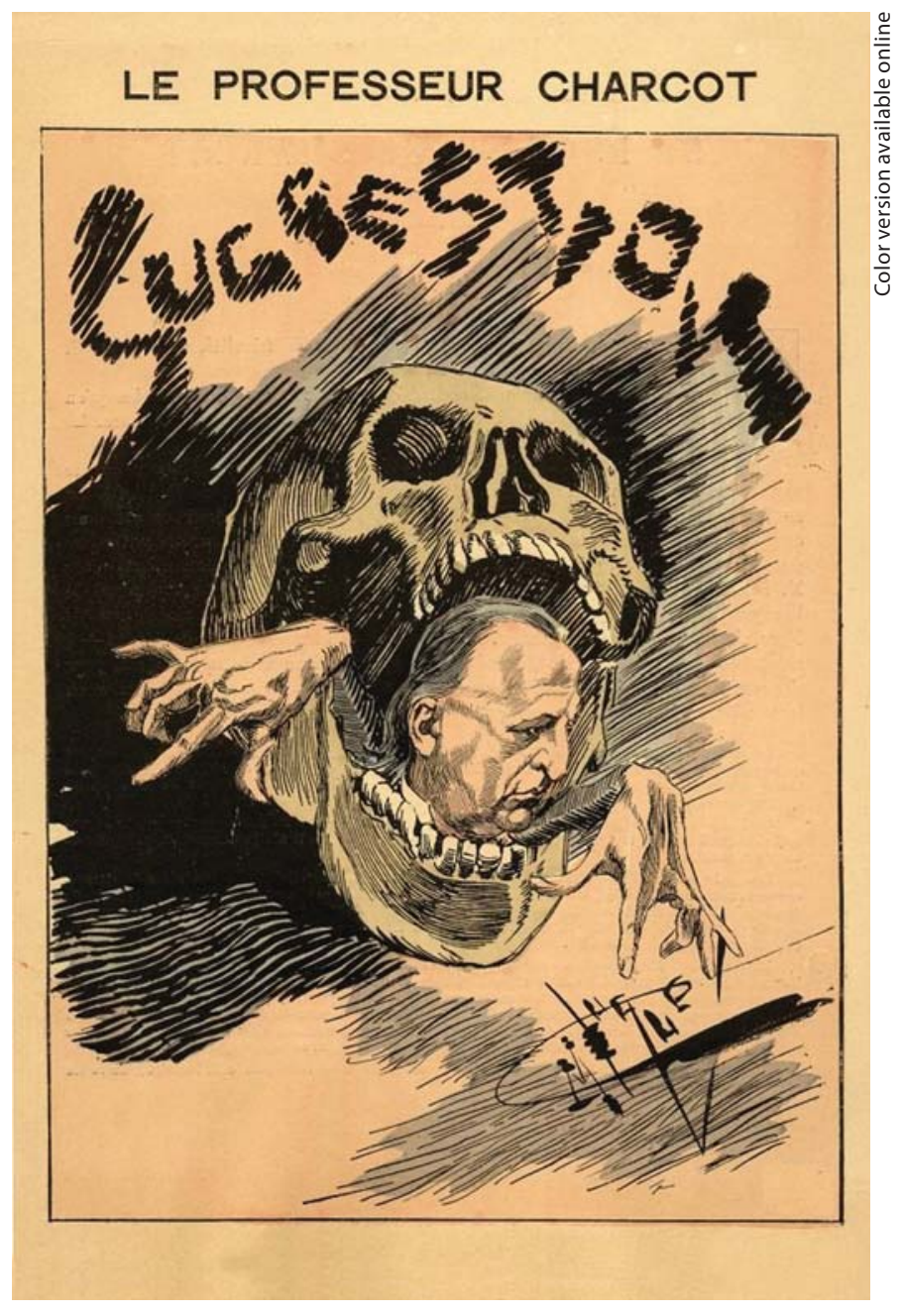

Fig. 2. Sketch of Jean-Martin Charcot at the time when hypnotic suggestion and 'mesmerization' were becoming highly popular in the public.

nique, Gérard Encausse (also known as 'mage Papus'), in parallel, and successfully, for occult practices in secret societies. Charcot considered hysteria as a 'neurosis' with an organic basis, but with no demonstrable cerebral damage and where a 'dynamic lesion' of the brain was responsible for the 'stigmata' (sensory dysfunction, hyperexcitability, visual field narrowing), i.e. permanent clinical features in patients who were also prone to paroxysmal fits (grandes crises d'hystérie) [6]. The 'dynamic lesion' was emphasized by Charcot in order to explain the organicity of hysteria in the absence of a morphological lesion. However, Charcot's views on hysteria evolved over time, frequently in contradictory ways [7]. Shortly before his death in 1893, he started to introduce psychological con- 
siderations, which had already been mentioned by Bénédict Augustin Morel, Charles Lasègue and Jules Falret in the early 1880s [3]. For him, 'trauma' became a critical factor which acted both as a triggering factor and as a mental representation after an often prolonged latency phase, a concept which was at the origin of the first ideas developed on hysteria by Freud and Breuer in the 1890s [7].

Probably influenced by Charles Richet's work on 'provoked somnambulism' in 1875 [8], Charcot started to use hypnosis with hysterics in 1878 . His ideas were summarized in Richer's book on 'hystero-epilepsy' in 1881, where hysteria and epilepsy were both considered as organic neuroses with no visible brain lesions [9]. Charcot and his school considered the ability to be hypnotized as a clinical feature of hysteria, and they repeatedly used this phenomenon in public demonstrations, which became popular shows among an intellectual, nonmedical following [10]. For the members of the Salpetrière School, susceptibility to hypnotism was synonymous with disease, i.e. hysteria, although they later recognized, during a prolonged quarrel with Hippolyte Bernheim and the Nancy School [11], that grand hypnotisme (in hysterics) should be differentiated from petit hypnotisme, which corresponded to the hypnosis of ordinary people [6]. During these controversies, medical-legal aspects addressing whether hypnosis could or could not influence certain people to commit reprehensible or criminal acts soon appeared. Charcot himself took firm positions against this hypothesis [12], but Gilles de la Tourette, who always remained faithful to Charcot's ideas, played the most critical role in these discussions.

\section{Charcot's Faithful Disciple: Georges Gilles de la Tourette}

Georges Albert Édouard Brutus Gilles de la Tourette $[2,13,14]$ was born on October 30,1857, in Saint-Gervais near Châtellerault, and started his medical studies in Poitiers when he was 16. After going to Paris in 1876, he became an interne provisoire in 1881 and interne titulaire in 1882, working with Charcot in 1884 and the medicallegal expert Paul Brouardel in 1885, before doing his doctoral thesis on gait disorders in 1886. After his appointment as Charcot's chef de clinique in 1887, his career closely followed that of his mentor's until Charcot's death in 1893 (the 'black year', as Gilles de la Tourette also lost his 5 -year-old son to meningitis and was assaulted at his home). In 1892, he was a candidate in the agrégation pro-

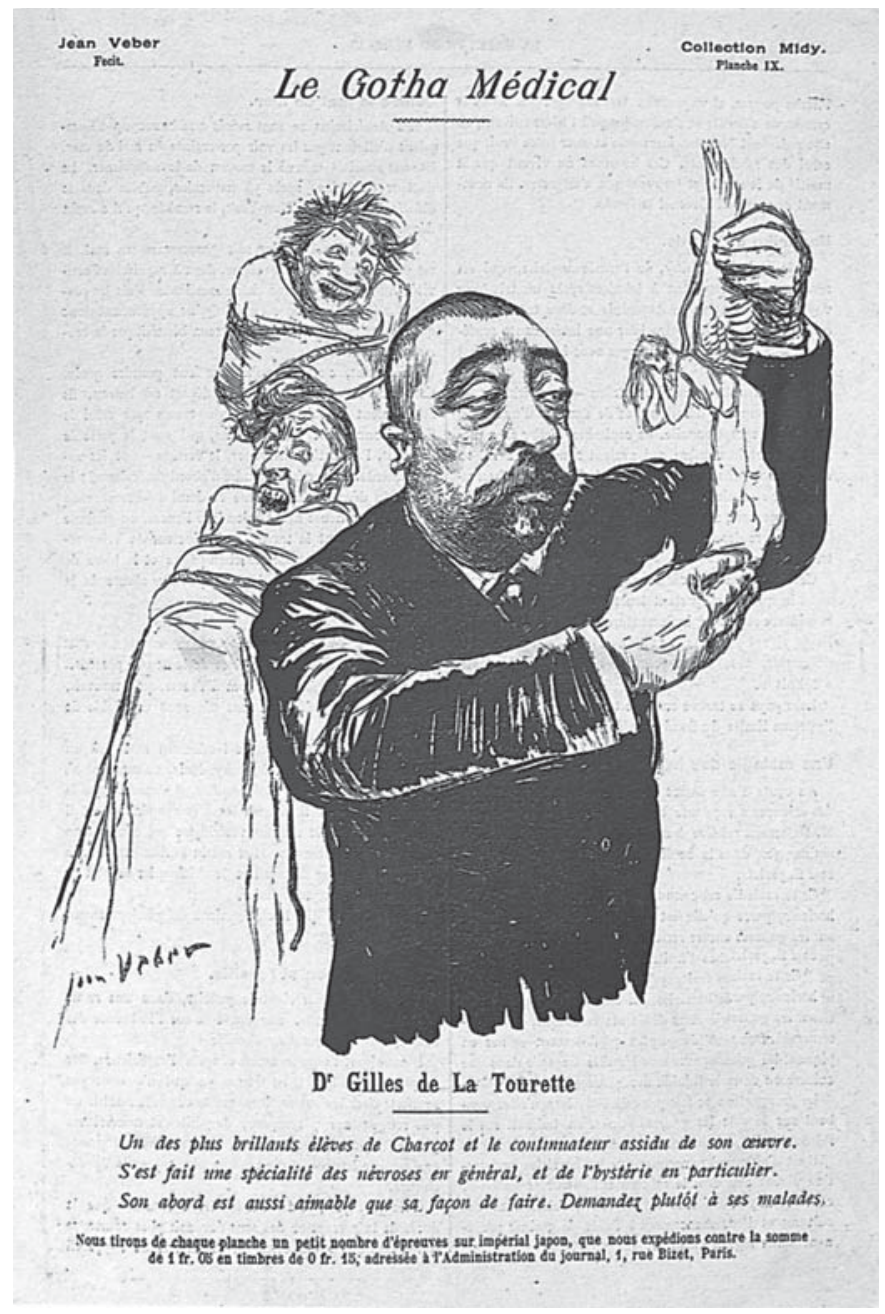

Fig. 3. Sketch of Gilles de la Tourette by Jean Veber, from Le Gotha Médical, suggesting a rather 'firm' therapy for agitated patients. The caption says that he is the continuator of Charcot's work, with a specialty in hysteria, and that 'his personal contact is as lovely as his own way to practice. Ask his patients about it'. At that time, Gilles de la Tourette showed the first signs of behavioral dysfunction associated with general paresis.

fessorship contest along with his predecessor, Charcot's former chef de clinique Babinski. Both of them were rejected after Bouchard, the president of the jury and former intern of Charcot, used intrigue to eliminate his former master's protégés in favor of his own candidates. But contrary to Babinski, Gilles de la Tourette became a candidate again and was accepted as a professor a couple of years later [15]. His scientific production is now dominated by his 1885 report on an affection nerveuse caractérisée par de l'incoordination motrice accompagnée 
d'écholalie et de coprolalie [16], named tic convulsif by Charcot, which subsequently became identified as Gilles de la Tourette's syndrome. His interests were not limited to medicine, but included history and literature, as shown by his works on Théophraste Renaudot and the theatre. When addressing hypnotism and hysteria, he also studied ancient historic reports, such as the cases of the 'possessed nuns' at Loudun of 1634 [17]. In 1888, he founded the Nouvelle Iconographie de la Salpêtrière with Albert Londe and Richer, and in 1900, with the help of Bourneville, he was appointed chief physician of the Exposition Universelle. Gilles de la Tourette was jovial and emotional; Freud described him as an 'authentic meridional' [2], even though he did not come from the South of France. During the last months of the century, he started to show a disturbed behavior (fig. 3), which worsened and required that he leave Paris for Switzerland with his family and Charcot's son, Jean-Baptiste. On May 28, 1901, Charcot had him committed to the Lausanne Psychiatric Hospital in Cery, using a deceptive trick (Jean-Baptiste told him that a famous patient was waiting in Cery to be examined by him). Gilles de la Tourette was diagnosed with tertiary syphilis with general paresis (ironically a disease which he claimed, along with Charcot, had no relationship with syphilis). He never left this hospital (he was deprived of all his civil rights in 1902) and died there on May 22, 1904.

\section{Hypnotism and Crime}

Gilles de la Tourette's medical-legal interests, developed under his training with Brouardel (who authored with Charcot the preface of his student's 1887 book on the medical-legal aspects of hypnotism) [18], were not limited to hysteria and hypnotism, but also included topics such as abortion and political murder (he wrote a report on the anarchist murderer Ravachol) [2]. Additionally, he made an important statement on the necessity of committing mentally disturbed criminals to asylums rather than sentencing them to prisons. In this field, his friendship with the journalist and writer Georges Montorgueil was important in facilitating public awareness, as shown in 1894 with the Dr. Lafitte case in which Gilles de la Tourette and Montorgueil supported, via the newspaper L'Éclair, a practitioner who had been accused of performing an illegal abortion for a young woman [2].

In 1887, Gilles de la Tourette published his major work on hypnotism and its medical-legal aspects [18]. He dedicated it to Charcot and Brouardel, who had authored the preface. Gilles de la Tourette was faithful to his mentor's ideas that susceptibility to hypnotism was a feature of hysteria and that most crimes could not be committed under hypnosis, except certain rapes (but it was the victim who was hypnotized) and, possibly, thefts. According to him, there were three states of grand hypnotisme: lethargy, catalepsy and somnambulism, plus certain initial states (lucid lethargy, fascination and charm state) [18, pp. 103-109]. While the hypnotized subjects could be called 'automatons', they kept a conscious state, which made them unable to perform acts which would go against their inner nature. On the other hand, they could be submitted to certain reprehensible acts, such as rape, mainly while in the lethargic state, in which muscle relaxation is compatible with the forfeit ('a rag at the mercy of the first by-comer', p. 491). To support his views, Gilles de la Tourette quoted several famous rape cases, including the case of Marguerite A. in 1858, the Castellan case in 1865, the Lévy case in 1878 and the Maria F. case of Ladame in 1881 . He vehemently criticized assumptions by Bernheim and Jules Liégeois from the Nancy School [19] that other crimes (with the exception of rare cases of theft) could have been committed by innocents malevolently hypnotized. For him, Liégeois's hypnotic experiments with fake weapons [20] were biased and artifactual, and did not support a significant role of hypnotism in real-life crimes. Gilles de la Tourette also complained of the current fashion of charlatan esoteric practices using hypnosis, advising that hypnotism should be reserved for medical use in a small number of specific patients (i.e. hysterics). A major public debate occurred in 1888 on the occasion of the affaire Chambige, when the 22-yearold Henri Chambige was found wounded beside the naked corpse of the older Madeleine Grille, a well-respected married woman. Bernheim argued that the woman had been hypnotized, raped and killed by Chambige, who subsequently attempted suicide. However, many controversies arose and even the famous magistrate Gabriel Tarde claimed that 'this is love, which is hypnosis!' [21]. Two years later, Charcot published an article on 'Hypnotism and crime' in the Forum of New York, a nonmedical American magazine, in which he reaffirmed that the only crime associated with hypnosis was rape [22], while Gilles de la Tourette published his opus magnum on hysteria 'as taught at La Salpêtrière School' between 1891 and 1895 [6], the proofs of which Charcot was correcting on the trip to the Morvan region, with Isidore Straus and GeorgesMaurice Debove, during which he died. 


\section{Against the Nancy School}

The most animated and public controversy between the Salpêtrière School and the Nancy School took place during 1889-1890 on the occasion of the Eyraud-Bompard case ('Gouffé's trunk'), which was summarized in a book the following year by the forensic expert A. Lacassagne [23]. The story fascinated the press and the public (fig. 4). In short, Gabrielle Bompard lured the bailiff Gouffé to her apartment, where the young woman managed to have him sit on a chaise longue, behind which her lover Michel Eyraud had hidden a hanging system which he could operate from behind a curtain. During preliminaries, Gabrielle sat on Gouffé's knees and, as if in play, she slipped the belt of her red peignoir around his neck and attached it to the prepared swivel. Eyraud pulled on the other end of the cord system, hanging Gouffé who died within two minutes. The murder was a flop, since no money could be found on the bailiff or at his office, and the murderers left Paris for Lyon the next day with a huge trunk, which Gabrielle had bought in London, containing the victim. They abandoned the corpse near Lyon and destroyed the trunk, before fleeing. After several months of investigations, Gabrielle finally gave herself up, while Eyraud was arrested later. The inappropriate, childish, indifferent and seductive behavior of Gabrielle was immediately observed, resulting in her lawyer contending that she had been hypnotized by Eyraud in the planning and execution of the murder [24]. Bernheim supported this hypothesis [19], which was reinforced by the fact that Jules Voisins was able to hypnotize Gabrielle several times in jail. Because of a broken leg, Bernheim could not attend the trial and was replaced by Liégeois, who put forward his own experiments of suggested murder during hypnotism using fake weapons [20]. However, his arguments were demolished by Brouardel, Gilbert Ballet and Auguste Alexandre Motet, who closely followed the Salpêtrière views that except for rape, no crime - particularly murder - could be the consequence of hypnotism. They concluded that Gabrielle had no mental disease, but was an incomplete being with a total lack of moral sense contrasting with good intellectual development. Eyraud was guillotined, and Gabrielle was sentenced to twenty years. In 1891, Gilles de la Tourette published a famous épilogue, followed by correspondence between him and Bernheim [25], in which he fully supported the conclusions of the trial after the report by Brouardel and his colleagues. However, this 'victory' was not without collateral damage for the Salpêtrière School. Private letters from Charcot to Gilles de la Tourette show that the for-

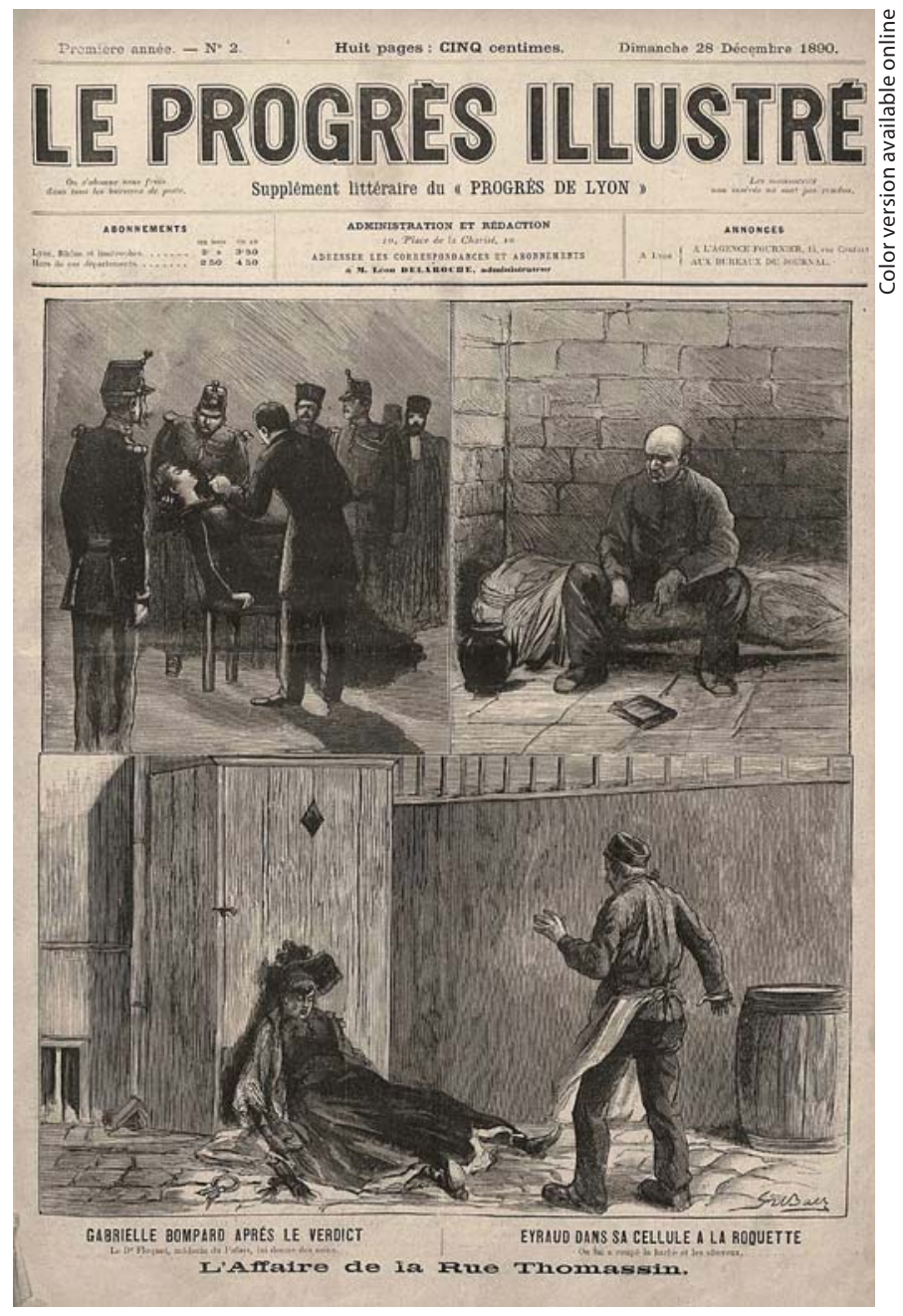

Fig. 4. Page of the newspaper Le Progrès Illustré showing Gabrielle Bompard and Michel Eyraud during 'Gouffé's trunk' case trial, on which Gilles de la Tourette wrote a famous épilogue denying the role of hypnotism in the murder of Toussaint-Augustin Gouffé.

mer was considerably disquieted by the controversy, which had considerably altered the image of medical hypnotism. According to Charcot: 'I am very anxious. Bernheim did not know and I have the proofs of your épilogue. Did he change his mind, and what to do (...)?' [2]. Two years later, Gilles de la Tourette remembered that his mentor was deeply affected by the outcome, and that he believed that hypnotism had been damaged for at least ten years [2].

In his épilogue [25], Gilles de la Tourette criticized Liégeois's hypnotic experiments of suggested murders with fake weapons [20]. However, it is striking that a few years 


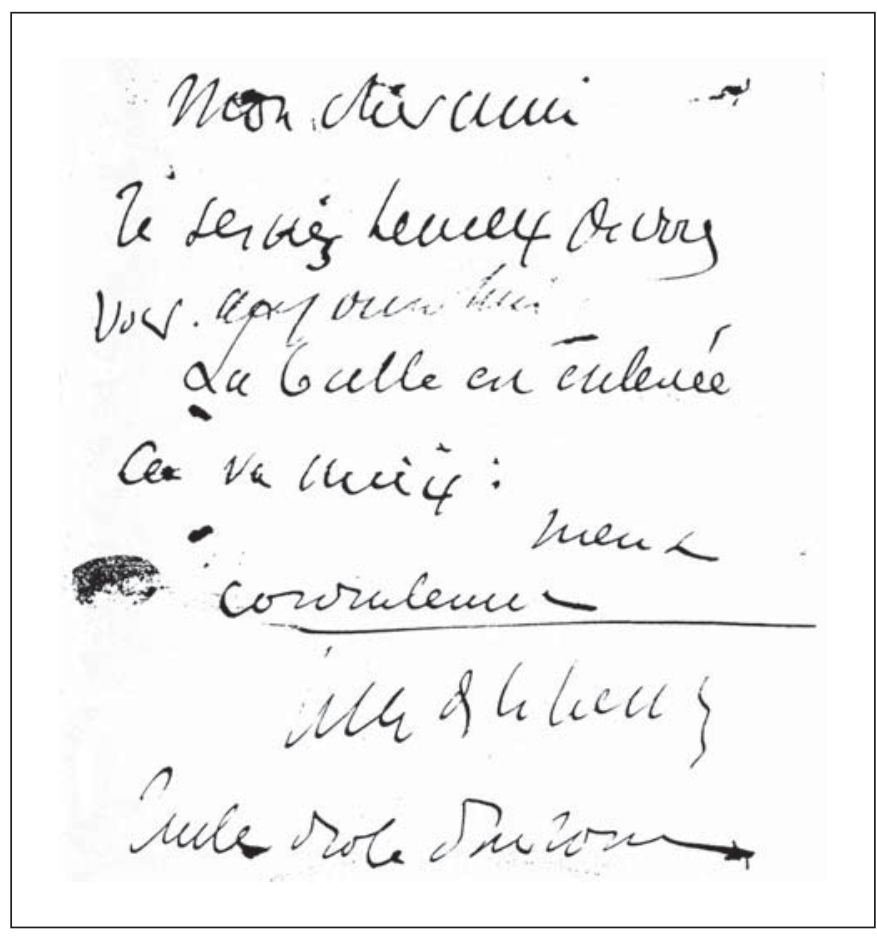

Fig. 5. Letter written by Gilles de la Tourette to his friend, the journalist Georges Montorgueil, the same evening he was shot by Rose Kamper-Lecoq. The writing is uneasy, but Gilles de la Tourette reassures Montorgueil and explains that the bullet has been removed, ending the letter with the comment ' What a strange story' ('Quelle drôle d'histoire').

before, he had done similar experiments in the Salpêtrière laboratory, which he reported in detail in his 1887 book on hypnotism [18]: H.E., a hysteric patient from the service, was told under somnambulism to shoot an intern (Mr. B.) after coming out of her hypnotic state because he was not treating her well. She was given a ruler and was told that it was a gun. She refused to give it back after being brought out of her hypnotic state ('she would kill the person who would try to take it from her'). When Mr. B. came in, she waited until he was close enough and 'shot' him, subsequently explaining in cold blood that this was normal since his treatment of her was poor. Gilles de la Tourette continued with the even more famous case of Blanche Wittman, the celebrated hysteric patient fainting in Babinski's arms in front of Charcot in the 1887 painting by Brouillet, who stayed at La Salpêtrière between 1879 and 1893, before going to work at Marie Curie's laboratory. Gilles de la Tourette put her under lethargy with a gong noise and under somnambulism with a friction on the vertex. The experiment took place in front of a rather large audience, which included the playwright Jules Clarétie. Blanche was told to poison Mr. G. as an order. When she was brought out of her hypnotic state, Mr. G. came in and she offered him some 'poisoned' beer. While she was under hypnosis, Gilles de la Tourette had shown her that he had 'poisoned' the beer in question. She used some manipulative words to have Mr. G. drink and even accepted to be kissed by him as an 'exchange'. After the 'death' of Mr. G., Blanche never confessed to the poisoning during a fictitious investigation, and Gilles de la Tourette concluded that Blanche had shown 'all feminine seductions, in such a natural way, that an uninformed person would certainly have been deceived'. These case reports illustrate the inner contradictions of the Salpêtrière School in the controversy with the Nancy School. Nevertheless, Gilles de la Tourette himself evolved little on this issue after Charcot's death, and several years later, he still mentioned that he did not accept the views of the Nancy School on murders committed under hypnotism [2].

The ambiguous, sexually flavored communication between the Salpêtrière doctors and their hysteric patients is well demonstrated by the 'kiss' episode, and it should be seen in the perspective of the time, when the notion that hysteric women were seducers was building up. While susceptibility to hypnosis was emphasized as a constitutive feature of hysteria, the concept was simultaneously somewhat inverted with the issue of men being put under influence (i.e. 'hypnotized') by seductive, manipulative women. Gouffe's trunk case was a good example in highlighting Gabrielle Bompard's childish, apparently irrational, but in fact emotionally and sexually manipulative, behavior in such a way that she was even depicted as a 'cold monster' [26].

\section{Criminal Hypnotism at Home?}

Gilles de la Tourette also experienced in his private life the consequences of the particular atmosphere which surrounded hypnotism in the belle époque, when on December 6, 1893, he was shot - for real - at his home in Paris by Rose Kamper-Lecoq, a 29-year-old former patient from La Salpêtrière and Sainte-Anne who later claimed that she had been hypnotized from a distance [2, 13]. Gilles de la Tourette had just published a newspaper interview with Montorgueil against the unwarranted use of hypnotism and 'mesmerization', and this may have been a trigger to the assault [14]. Rose asked him for some money, claiming that she was without resources because 
her hypnotism sessions had altered her will, and shot him when he refused. There were three shots, with only the first one reaching its target. Fortunately for Gilles de la Tourette, it resulted in only a superficial occipital wound, and he was even able to write to Montorgueil about the event the same evening (fig. 5). The patient did not try to escape, and was quietly sitting in the waiting room when people arrived. The story was reported in detail by Georges Guinon in Le Progrès Médical because rumors of an attempted murder under hypnotism were spreading; however, the investigation report clearly showed that interpretative delusional thoughts were the reason of the act [27]. The patient claimed that she 'knew' that Gilles de la Tourette was in love with her, and that previous hypnotism sessions had transformed her by annihilating her will, allowing a new spirit, now inside her, to force her to kill him. She also pretended to be in communication with the czar and had already threatened other famous people in Paris. Brouardel, Ballet and, later, Jules Falret declared her insane with 'fixed ideas', and she later at- tacked a nurse with a fork. For this reason, and contrary to what has been previously reported [14], there was never a trial and the patient spent several years in mental hospitals; the association of hypnotism with the assault was definitively discarded.

The path initiated and followed by Charcot on hysteria and hypnotism at La Salpêtrière was faithfully followed by Gilles de la Tourette. However, he stopped working less than eight years after his mentor's death, and we do not know whether his evolution on that topic would have been different with time. Other close students of Charcot, such as Féré, Pierre Janet and Alfred Binet, distanced themselves from an intransigent position on the NancySalpêtrière controversy $[3,24]$. This was also the case of Babinski, who in 1891 was still giving 'pure Charcotesque' lectures on hysteria and hypnotism at La Salpêtrière [28], before seriously revising his views in a process which would lead to the concept of pithiatism ten years later [29].

\section{References}

1 Daudet L: Devant la douleur. Paris, Bernard Grasset, 1931

2 Duncan G: Gilles de la Tourette: Aspects connus et méconnus de sa vie et de son œuvre. Poitiers, Impression des thèses, 1995.

3 Drèze C: Charcot, 1825-1893. Louvain Méd 2001;120:33-66.

4 Guillain G: J.M. Charcot, 1825-1893, sa vie, son œuvre. Paris, Masson and Cie, 1955

5 Luys J: Les émotions dans l'état d'hypnotisme. Paris, JB Baillière et Fils, 1890.

6 Gilles de la Tourette G: Traité clinique et thérapeutique de l'hystérie d'après l'enseignement de la Salpêtrière. Paris, Librairie Plon, 1891 (vol 1), 1895 (vol 2 and 3).

7 Derouesné C: Pithiatism versus hysteria; in Philippon J, Poirier J (eds): Joseph Babinski, A Biography. Oxford, Oxford University Press, 2009, pp 297-319.

8 Richet C: Le somnambulisme provoqué. J Anat Physiol Norm Pathol 1875;11:348-378.

9 Richer P: Études cliniques sur l'hystéro-épilepsie ou grande hystérie. Paris, Adrien Delahaye et Émile Lecrosnier, 1881.

10 Goetz CG, Bonduelle M, Gelfand T: Charcot: Constructing Neurology. Oxford, Oxford University Press, 1995.
11 Bogousslavsky J, Walusinski O: The forgotten Gilles de la Tourette: practitioner, expert, and victim of criminal hypnotism. Submitted.

12 Goetz CG: Medical-legal issues in Charcot's neurologic career. Neurology 2004;62:18271833.

13 Legendre P: Gilles de la Tourette. Paris, Librairie Plon, 1905.

14 Lees AJ: Gilles de la Tourette, the man and his time. Rev Neurol (Paris) 1986;142:808816.

15 Philippon J, Poirier J: Joseph Babinski: A Biography. Oxford, Oxford University Press, 2009.

16 Gilles de la Tourette G: Étude sur une affection nerveuse caractérisée par de l'incoordination motrice accompagnée d'écholalie et de coprolalie (Jumping, Latah, Myriachit). Arch Neurol (Paris) 1885;9:158_200.

17 Légué G, Gilles de la Tourette G: Sœur Jeanne des Anges: autobiographie d'une hystérique possédée, d'après le manuscrit inédit de la bibliothèque de Tours. Paris, Bourneville, 1886.

18 Gilles de la Tourette G: L'hypnotisme et les états analogues du point de vue médico-légal. Paris, Librairie Plon, 1887.
19 Bernheim H: Les suggestions criminelles. Paris, Revue de l'hypnotisme, 1890, vol 266.

20 Liégeois J: De la suggestion hypnotique dans le droit civil et le droit criminel. Séances et Travaux de l'Académie des Sciences Morales et Politiques 1884;122:155-240.

21 Tarde G: L'affaire Chambige. Arch Anthropol Crim 1889;4:92-108.

22 Charcot JM: Hypnotism and crime. Forum of New York 1890;9:159-168.

23 Lacassagne A: L’affaire Gouffé. Lyon, A. Storck, 1891

24 Plas R: Hysteria, hypnosis, and moral sense in French 19th-century forensic psychiatry. The Eyraud-Bompard case. Int J Law Psychiat 1998;21:397-407.

25 Gilles de la Tourette G: L'épilogue d'un procès célèbre. Paris, Le Progrès Médical and Lecrosnier et Babé, 1891.

26 Harris R: Murders and madness. Medicine, law, and society in the fin de siècle. Oxford, Oxford Historical Monographs, 1989.

27 Guinon G: Attentat contre le Dr. Gilles de la Tourette. Progr Méd 1893;446.

28 Babinski J: Hypnotisme et hystérie. Leçon faite à la Salpêtrière le 23 juin 1891. Paris, G. Masson, 1891.

29 Babinski J: Définition de l'hystérie. Rev Neurol (Paris) 1901;9:1074-1080. 